\title{
ERRATA.
}

Page 12, lines 16 and 17 , for one hundred read three hundred and for me thousand read six hundred.

Page 17 , line 2 , dele first letter in the line.

Page 168, line 12, page 177, lines 13 and 14, and page 271, line 10, for Lemna trisulca read Spirodela polynhiza.

Page 209 , line 2 of foot-note, after but insert represchts.

Page 256, line 7, and page 266, line 19: snowi n. s. has been shown to be hieroglyphica, o'.

Page 257, insert as line 8 as follows: -ken to the office produced young in ten days. The

Page 272, line 13, for $P$. biguttatus read Pompilus biguttatus.

Page $₫-8$, Plate V., 16, after view insert as follows: $a$, mentum; $b$, labial rudiment; $c$, maxillary palpi; $d$, maxilla; $e$, labrum; $f$, autenna; $g$, eye; $h$, mandible.

Page 286, line 11, drop initial the one line.

Page 386, line $\vec{i}$, for Comstocki read Comstock.

Page 399, line 17, for specimens read specimen.

Page 411 , line 10, for Michaelson read Michcielsen.

Page 441, line 3 from bottom, for 66 read 68 .

Page 445 , line 10 from bottom, for 57 read 58.

Page 466, line 1 frum buttom, for Cypria read Cypris. 
Article XIII.-Descriptions of five New Species of Scale Insects, with Notes. By Willis Grant Johnson, A. M.

\section{ASPIDIOTUS Bouché.}

Aspidiotus forbesi sp. n. (Plate XXIX., Fig. 1-5.)

Scale of female.-The general shape of the scale of the female is nearly circular (see Plate XXIX., Fig. 1,b), but it varies according to the position of attachment, as scales under a fold in the bark or on some uneven surface are very irregular in outline. The color is dirty grayish in fresh specimens, but darker when driel. The exuviæ are usually slightly to one side of the center, and covered with excretion; the nipple-like prominence in rubbed specimens is reddish or yellowish brown, surrounded by a band a little darker than the margin. Scale rather convex, delicate, and easily torn when removed from fresh material. It varies considerably in size. the average diameter being about $2 \mathrm{~mm}$.

Scale of male. -The scale of the male is elongate-oval (Plate XXIX., Fig. 1, c), and is darker and not so delicate as the scale of the female. Nipple-like prominence situated between the center and the anterior margin, usually covered with excretion, and when rubbed or broken of about the same color as that of the female scale. Margins thin and delicate, and lighter than the rest of the scale. Length about $1 \mathrm{~mm}$., width about $5 \mathrm{~mm}$.

Eggs.-The eggs are pale yellow, elongate oval, and about $.22 \mathrm{~mm}$. long by $.12 \mathrm{~mm}$. wide.

Young.-The young larva (Plate XXIX., Fig. 5), when first hatched, is pale yellow and of the general outline shown in the figure. Antennæ apparently five-jointed and lighter colored than body; last joint as long or longer than the combined leng:th of the other four. Eyes prominent, brownish or purplish black. Legs stout and lighter 
than body. Segments distinct. Median lobes conspicuons, with two long anal filaments projecting from between them.

Hature male.-The mature male (I'late XXIX., Fig. 2) varies considerably in color even in the same brood, some individuals being reddish brown, while others are yellowish. Legs, antenner, and style lighter than the body. Eyes dark purplish. Antenne nine-jointed and about .35 mm. in length. Wing expanse nsually about $1 \mathrm{~mm}$.; wing about $.44 \mathrm{~mm}$. in length and half as wide. Thoracic band and margins of shield a little darker than body. Poisers prominent, with terminal hooks. Length of body, .48 mm.; style, .26 mm.; total length, $.74 \mathrm{~mm}$.

Mature female.-The body of the mature female (Plate XYIX., Fig. 3) is yellowish, rather robust, and of the general outline shown in the illustration. The last segment (Plate XXIX., Fig. 4) is darker than the rest of the body and presents the following charactel's:

There are five groups of spinnerets: the anterior group includes from 1 to 3 , usually 1 or 2 ; the anterior laterals, from 3 to 7 , and the posterior laterals, from 3 to 5 . The number of spinnerets is variable, and in many instances they are very scattering. There are two pairs of lobes: the median pair prominent, about as wide as long, and usually notched on the lateral margin; the second pair about half the size of the first, rounded or more or less pointed. Plates inconspicuous or absent, spines prominent, situated as shown in the illustration, the second about as far from the first as the third is from the second, the fourth about twice as far from the third as the third is from the second. Rather deep incision between first and second lobes. Club-shaped organs, about which the spinnerets are grouped, arranged as shown in the illustration. Anal opening about as far from the incision as the spines are long.

This species occurs on wild and cultivated cherry, apple, pear, plum, quince, currant, and possibly on 
honey locust and mountain ash. Common in Illinois; collected by the author.

Types in collections of the Illinois State Laboratory of Natural History and of the United States National Museum, and in the author's collection.

I first discovered this species on English morello cherry-trees in Champaign, Illinois, December, 1894. It is very generally distributed over Illinois, and from what I have seen of its attack I consider it the most dangerous scale insect of the orchard now established in the State. Cherry scems to be its favorite food plant, and I have found it on wild cherry at Champaign, Decatur, Edgewood, and Eldorado. I therefore propose for it the popular name, "cherry scale." Its specific name is in honor of Professor S. A. Forbes, State Entomologist of Illinois. It attacks the trunk and branches of the cherry and is found occasionally upon the leaves and fruit. In June, 1896, I found a few partially matured scales of this species on cherries; July 6 , 1895 , I collected several currants on which they were found; and August 14, 1895, I gathered several apples which contained scales of fully developed females of the clierry scale.

I have bred the following seven species of hymenopterous parasites* from this scale insect: Prospalta murtfeldti (How.), Prospalta aurantii (How.), Perissopterus pulchellus (How.), Signiphora nigrita (Howard MS.), Amhenophagus chionaspidis (Aur.), Ablerus clisiocampo (Ashm.), and an undetermined species belonging to the Encyrtinæ. Aside from these parasites, I have very often seen small whitish mites under the scales, especially under male scales containing pupæ, and in many cases the pupæ were dead. The twice-stabbed ladybug, Chilocorus bivulnerus, and its larva, also feed voraciously on this scale.

*All the hymenopterous parasites mentioned in this paper have been examined and determined by Mr. L. O. Howard, United States Entomologist, of Washington, D. C. I am also under obligations to Mr. Howard, to his Assistant Mr. Theo. Pergande, and to Prof. T. D. A. Cockerell, for various favors rendered in the examination of coccid material. 
This species hibernates as a partially matured insect, and is double brooded in the latitude of Springfield, Illinois. The mature males begin to emerge about the middle of April, and the first brood begins to appear early in May; but young and eggs of the same brood are often found as late as June 20. The mature males for the second brood begin to appear about July 10 and continue to emerge until about August 1 . The roung of the second brood first appear about the first week in August, and may be found until late in September. It is quite possible that there are three broods in the southern part of this State.

The species is related to Aspidintus ancylus Putnam, but may be readily distinguished from that species by its size, its coloration, and by the presence of the second pair of lobes and the spimnerets on the last segment. The mature male is larger and has a greater wing expanse than ancylus.

Aspidiotus comstocki sp. 11. (Plate XXX.; and Plate XXXI., Fig. 1 and 2.)

Scale of female. - The general shape of the scale of the female depends almost entirely upon its position on the leaf. It is generally attached close to the midrib, reins, or veinlets on the under side of the leaf, and conforms, to a certain extent, to the angle formed by the reins. The commonest form is that shown at $c$, Fig 6, Plate XXX. The side next the vein is slightly curved, sometimes nearly straight, and the scale raries in length from 1.5 to $2 \mathrm{~mm}$., and in width from 0.5 to $1 \mathrm{~mm}$. The exuria are near the center of the margin next the vein. The large. well-developed, rather flat scales are rreambuff. excepting that part which covers the exuvie. which varies from yellowish to reddish brown and is often concolorous.

Scale of male.-The mature male is cream-buff or grayish white. more or less elongate-oral, and about $1 \mathrm{~mm}$. long by $0.5 \mathrm{~mm}$. wide. The larval seale is at the an- 
terior extremity and usually laterad of the meson. The scale is extremely delicate, and semitransparent after the male lias emerged. The outline of the male pupa can be plainly seen through the scale. The general form of the male scale is shown at 6 , Fig. 1, Plate XXX.

Eggs.-The eggs are pale yellow.

Young.-The young larve are long-oval, pale yellow, the mouth parts prominent and doubled on themselves. Antennæe prominent, little lighter in color than the body ; apparently five-jointed, the last two joints much longer than the rest; the last joint with a long transparent hair at its apex. The median pair of lobes conspicuous, with two long delicate hairs projecting from their bases.

Mature male.-The mature male (Plate XXX., Fig. 2, a) is light yellow; eyes dark purple, almost black; antennæe yellowish and of the form shown at 6 , Fig. 2; legs and style light yellow; thoracic shield prominent, with its margins and the band brownish; wings prominent, somewhat iridescent. Lengtl about .62 mm.; style, $.22 \mathrm{~mm}$.

Hature female. The body of the mature female (Plate XXXI., Fig. 1,) is rather flat, pale yellow, and of the general shape shown in the illustration. The last segment is a little deeper yellow than the rest of the body and presents the following characters:

There are four groups of spinnerets; the anterior lateral groups usually composed of six; the posterior lateral, of four. 'There are two pairs of well-developed lobes, the second pair usually rounded, often as loug and as broad as the median pair; the median pair commonly notched on the lateral margins near the tip. Plates conspicuous and generally of the form shown in Fig. 2, Plate XXXI. Between the first and second lobes they are more or less toothed and project nearly to the end of the first lobe; laterad of the second lobe there is a broad, circular fringe; still further laterad and between the third and fourth spines there are three large compound 
plates. the one next the fourth spine with two forks, the other's with three, as shown in the illustration. spines prominent; the first pair near the lateral margin of the base of the median lobes; the second on the lateral margin of the base of the second lobes; the third and fourth on the body margin between the plates as described above. There is a deep incision between the lobes and also laterad of the second lobe. Anal opening. conspicuous, and about as far from the base of the median lobes as the lobes are long:

This species was found on leaves of sugar maple, Acer sacclurinum, received firom Dr. Jacob Schneck, of Mt. Carmel. Illinois, and from Mr. R. H. Pettit, of Ithaca, New York, and I have found it on sugar maple at Champaign and Decatur, Illinois.

Types in collections of the Illinois State Laboratory of Natural History and of the Cnited States National Museum, and in the author's collection.

This insect has been very abundant on sugar maple for the past two years at Mt. Carmel, Illinois. It attacks the leares. living in great numbers on the under side (see Plate XXY.. Fig. 1, $a$ ), and causing yellowish spots on the upper surface. The spots become more conspicuous as the insects mature, and the leaves fall prematurely. It hibernates in the partially mature state uncler the leaf buds. I hare not found this insect on any other tree than the sugar maple, and as it attacks the leaves and is rarely found on the branches, I have proposed for it the popular name, "maple leaf scale." The specific name proposed is in honor of Prof. J. H. Constock, of Cornell University, who first gave me instruction concerning this interesting group of insects.

A. comstocti is related to Aspidiotus urce ('omstoek, but its occurrence on maple and the concolorous exuviæ should facilitate its recognition. It is also near $A$. townsencli Clill., a species recently describer from Mexico. We now have four closely allied forms. which Prof. Corkerell has ralled the mor group. and has arranged as follows: 


\section{Illinois State Laboratory of Natural History.}

1. wece Comstocki,

2. coloratus Ckll.,

3. town sendi Ckll., Eastern States.

4. comslocki Johnson, on sugar maple... Illinois and New York.

The scale of coloratus is pale orange-brown, the exuviæe concolorous; that of comstocki cream-buff, the exuviæ variable; that of uve light brownish, the exuviæ yellow; and that of townsendi grayish white, the exuviæ pale orange. In the lobes and plates, as also in the spinnerets, these forms are variable; but comstocki is noticeable for the comparatively large size of the second lobes.

Aspidiotus æsculi sp. n. (Plate XXXI., Fig. 3; and Plate XXXII., Fig. 1-3.)

Scale of female.-The scale of the female is circular (Plate XXXI., Fig. 3,c), rather convex, and varies in diameter from 1.5 to $3 \mathrm{~mm}$, averaging about $2.5 \mathrm{~mm}$. The general color of the scale is dirty gray, conforming usually to the color of the bark to which it is attached. The exuviæ are usually a little one side of the center, and covered with excretion. In rubbed specimens the protuberance indicating the position of the exuviæ is orange-red and surrounded by a band a little darker in color than the rest of the scale. The ventral scale is delicate, white, and adheres to the bark, leaving a whitish scar when the scale is removed.

Scale of male.-The scale of the male is elongate-oval (see Plate XXXI., Fig. 3, $b$ ), from 1 to $2 \mathrm{~mm}$. in length, and half as wide. It is considerably darker than the scale of the female. The position of the larval scale is marked by a nipple-like prominence situated between the center and the anterior margin of the scale. This prominence is usually covered with a slight excretion. When rubbed it is orange-red. The ventral scale is white and slightly thicker than that of the female.

Eggs.-The eggrs are pale yellow.

Young.-The young larva when first hatched is pale yellow, and in outline elongate-oval. Antennæ distinct and apparently five-jointed, the last joint as long or 
longer than the other four combined. Eyes large. Mesal lobes prominent, notched on their lateral margin, and with two long hairs projecting from between them.

Mature male.-The mature male (Plate XXXII., Fig. 1) is rellowish. Eyes prominent. Antenna prominent, and of the form shown in the illustration. Body stout. Legrs long, and a little lighter yellow than the body. Wings large, with well-dereloped pocket for the reception of the poiser. Thoracic shield with band distinct, and with margins indistinct in some specimens. Length about .60 min.; style $.39 \mathrm{~mm}$.

Mreture female.-The body of the mature female (Plate XXXII., Fig. 2) is orate, rather plump, and yellow. The last segment is a little darker yellow than the rest of the body, and presents the following characters (see Plate XXXII., Fig. 3):

There are four groups of spinnerets, the number in each group being extremely variable. The anterior laterals vary from five to seventeen, the average being about ten; while the posterior laterals vary from four to eleven, the average being about seven. The number is variable on opposite sides of the same individual. There is only one pair of lobes. They are nearly as broad as loug and notched on their lateral margin near the tip. Plates, simple and inconspicuous; one usually just laterad of the lobe, and two between the second and third spine. Spines prominent, arranged as shown in the illustration, and usually one pair on each segment. A rather deep incision just laterad of the lobe. Anal opening about twice as distant from the base of the lobes as the lobes are long. Curious club-shaped organs, as shown in figure, about which the spinnerets are gronped.

Found by the writer on buckeye, Esculus ralifornica, at Stanford Dniversity, California.

Types in collections of the Illinois State Laboratory of Natural History and of the United States National Iuseum, and in the anthor's collection. 
I found this insect very abundant on buckeye in Santa Clara county, California, in 1892. It attacks the trunk, branches, and smaller twigs, but so far as I have observed is not found upon the leaves. It colonizes most abundantly on the under side of the branches, and often accumulates in masses two or three scales deep. This is accounted for by the fact that many scales adhere so closily to the branches that the young larva are unable to get out, and therefore attach themselves to the bark underneath the scale. It is not an uncommon thing to find a dozen or more young larvæ attached in this manner underneath the scale of the parent insect, and as the scale is formed and the insect matures the old scales are naturally pushed outward. The color of the scale conforms so closely to that of the tree that it is very difficult to detect the scale, except where it is quite abundant.

I liave frequently bred a hymenopterous parasite, Prospalta murtfeldti Howard, from scales of this insect.

Aspidiotus ulmi sp. n. (Plate XXXII., Fig. 4 and 5.)

Scale of female.-The scale of the female is circular or nearly so, quite convex, with exuviæ central or slightly laterad of the center. Exuviæ in fresh specimens bright orange-yellow; but dirty whitish in old material. The color of the scale is either dirty whitish or tan-colored, the latter color being due to the covering of the corklike bark. There is a well-developed, snowy white ventral scale, which usually adheres to the bark when the scale is removed. The ventral scale often adheres to the dorsal scale, especially when the insects are massed together, completely enveloping the insect. The interior of the dorsal scale is also snowy white. Diameter usually about $1.5 \mathrm{~mm}$.

Scale of male.-The scale of the male is more or less circular, sometimes elongate-oval, of the same general color as the female scale. Ventral scale well developed and snowy white, usually about $.70 \mathrm{~mm}$. long. 
Eggs.-The eg's's are pale rellow and ovate.

Young.-The newly hatched larva is pale yellow and elongate-oval in outline. Antennæe apparently fivejointed, last joint longest. Iug's lighter than body.

Mature male.-The mature male is bright or lemonyellow in general color. The thorax is dark or brown. ish on the dlorsum; head about the same color; neck lighter. Antennæ rather brownish, with thick clusters of hairs. Front and median tibix brownish. 'Tarsi of hind legs dark, about the same color as fore tibiæ. Hind tibiæe with a dark band at base. Length about .65 mm.; style about .42 $\mathrm{mm}$.

Mature female. The body of the female is ovate, sometimes nearly circular (Plate XXXII., Fig. 4), lemonsellow in color, with the last segment (Plate XXXII., Fig. 5) brownish or amber, and presenting the following character's:

There are no groups of spinnerets, so far as I have been able to determine from a large series of balsam mounts. There is a curious, pretty constant group of club-shaped organs, as shown in the illustration. There is only one pair of lobes. They are very prominent, about as wide as long, notched on each side, and more or less rounded. The body wall is thickened for a considerable clistance laterad of the lobes, usually to the last plate. Plates distinct, about as long as the lobes; two laterad of the lobes, between the first and second spines, the one next to the second spine usually forked; four, as a rule, between the second and third spines, the one next the third spine usually forked and longest, and three, all simple, laterad of the third spine. Spines distinct; first pair on the lateral margin of the base of the lobes; the second and third just laterad of the incisions. Anal opening a little more than twice as distant from the base of the lobes as the lobes are long.

Found by the author on the trunk of a white elm, Ulmus americana, on the University campus, at Urbana, Illinois. Not common. 
Types in collections of the Illinois State Laboratory of Natural History and of the United States National Museum, and in the author's collection.

I have found this species on one tree only, and in very limited numbers. So far as I have observed it does not attack the branches, twigs, or leaves, but lives exclusively upon the new bark of the trunk, clustering between the cracks in the old bark. It often gathers in great numbers, and the masses of scales resemble small shells. I have not worked out its life history as to the number of broods, since it is of little consequence from the economical standpoint.

I have bred from this insect two species of hymenopterous parasites, Prospalta murtfeldti How., and Coccoph agus fraternus How.

\section{CHIONASPIS SignORET.}

Chionaspis americana sp. n. (Plates XXXIII. and XXXIV.

Scale of female.-The scale of the female is fawn-color at first, but becomes more or less bleached during the fall and winter mouths, presenting a dirty whitish appearance in the spring. The first larval skin is yellowish, the second is claret-brown, approaching a maroon, and is covered with slight secretion. The interior lining of the scale is snowy white, and when lemoved from the twig it leaves a whitish scar, the margins of which are very distinct. In general outline the scale resembles that of Chionaspis furfurus, but is mole convex. It widens near the posterior end of the second larval skin, some scales bending abruptly to the right or left, and others being straight. Length 2-3 mm.; width 1.5-2 mm.

Scale of male.-The scale of the male is snowy white, straight, tricarinate, about $.73 \mathrm{~mm}$. long; and $.30 \mathrm{~mm}$. wide; the sides rough and nearly parallel; larval skin yellowish 
Eggs.-The eggs are purplish, elongate-oval in outline, about $.22 \mathrm{~mm}$. long and $.15 \mathrm{~mm}$. wide.

Young.-The newly hatched larva (Plate XXXIV., Fig. 3 ) is $.22 \mathrm{~mm}$. long by $.13 \mathrm{~mm}$. wide, purplish, and of the form shown in the illustration. Antennæ prominent; eyes blackish. The anal filaments are inconspicuous except at base, and a little longer $(.15 \mathrm{~mm}$.) than the body is wide. Segments more or less distinct, with a row of dark spots along the lateral margin.

Iature male.-There are two forms of males: a perfect male with fully developed wings (Plate XXXIV., Fig. 1) and a pseudimago with rudimentary wings (Plate XXXIV., Fig. 2). In the former the wings are long. extending, when folded over the back, a little beyond the tip of the style, and the poisers are well developed (see Fig. 1); in the latter the wings are represented by mere stubs, as shown in Fig. 2, and the poisers are short and stout, lacking the terminal hook. Length of body varies from $.25 \mathrm{~mm}$. to $.35 \mathrm{~mm}$. In other respects the two forms present few characters that differ, and are in agreement as follows: the color is reddish brown; thoracie shield and band not distinct, conforming in general color to that of the rest of the body; the legs are stont, and lighter in color than the body; tarsi sparsely hairy (Fig. 1, c). Eyes prominent, nearly black; antenne vellowish, sometimes pinkish, tenjointed. covered with stout transparent hairs (Fig. 1, b). Style about $.20 \mathrm{~mm}$. long, and of nearly the same color as the legs. Segments of abdomen distinct.

Ifature female. - The body of the female is rough, deeply lobed (Plate XXXIV., Fig. 4), reddish brown, with the central portion somewhat purplish because of the eggs within. The last segment is yellowish and presents the following characters (Plate XXXIV., Fig. 5):

There are five grouns of spinnerets. The anterior group contains 20 to $2 \overline{7}$; the anterior laterals, 18 to 28 ; and the posterior laterals, 20 to 25. There are 
three pairs of well-developed and conspicuous lobes. The median pair are rounded, and unusually notched on the lateral margin near the tip; the second and third pairs are rather flat and broad, more or less notched on their margins. There are two plates between the second and third lobes, one of which is conspicuous and usually forked at the tip, while the other is short, simple. and sometimes inconspicuous. There is also a third plate, usually forked, just laterad of the third lobe. The spines are prominent and about as long as the plates. The first pair are situated near the lateral margin of the base of the first lobes; the second, about the middle of the base of the second lobes; the third, just laterad of the base of the third lobe.

Found on white elm, Olmus americana, throughout Illinois, by the writer, and in Minnesota, on the same species, by Mr. R. H. Pettit.

Types in collections of the Illinois State Laboratory of Natural History and of the United States National Museum, and in the author's collection.

This species is very common throughout the State, and has caused considerable damage to elms planted for shade in some of our larger cities. I have also found it abundant upon virgin timber, but only upon the elm. I believe it to be a native American insect, and propose for it the above-mentioned scientific name, and popularly term it the "American elm scale." From the character and nature of its attack it is clearly a dangerous species. It is two-brooded in central Illinois, the first brood appearing about May 1, and the second about July 1. It hibernates in the egg state. The average number of eggs under each scale is about one hundred and five. The female attacks the trunk and the branches; but the male is most abundant upon the trunk and leaves, although often found upon the branches. According to one season's observations, the peculiar pseudimaginal form of the male is very much 
more abundant than the true imago. The wingless form is very active, and runs with considerable freedom. I have repeatedly seen it copulating. The winged form is also very active, but is rarely seen. Gossyparia ulmi Geof., another coccid injurious to elm, is also peculiar in having two forms of males.*

I have bred two species of hymenopterous parasites, Perissopterus pulchellus (Howard) and Physcus varicomis (Howard), from this "American elm scale." I have also reared specimens of a parasite, presumably different from the above, but they were so badly damaged by accident that it was found impossible to determine them. Under some scales I have seen a very small mite among the eggs, and I have seen both the larva and adult of the twice-stabbed ladybug, Chilocorus bivulnerus, feeding upon this scale. So far as my observations go, the parasitic and predaceous enemies of this insect are to be considered as very trivial agencies in keeping the species in check. 


\section{EXPLANATION OF PLATES."}

\section{Plate XXIX.}

Fig. 1. Aspidiotus forbesi n. s.: $a$, infested cherry twig; $b$, scale of female; $c$, scale of male.

Fig. 2. Adult male of same.

Fig. 3. Adult female of same, showing eggs within body.

Fig. 4. Last segment of adult female.

Fig. 5. Young larva of same species.

\section{Plate XXX.}

Fig. 1. Aspidiotus comstocki n. s.: a, infested maple leaf; $b$, scale of male; $c$, scale of female.

Fig. 2. $a$, adult male of same; $b$, antenna; $c$, poiser; d, tarsus.

\section{Plate XXXI.}

Fig. 1. Adult female of Aspidiotus comstocki.

Fig. 2. Last segment of same.

Fig. 3. Aspidiotus aesculi n. s.: $a$, infested buckeye twig; $b$, scale of male; $c$, scale of female.

\section{Plate XXXII.}

Fig. 1. Adult male of Aspidiotus cesculi.

Fig. 2. Adult female of same.

Fig. 3. Last segment of female.

Fig. 4. Aspidiotus ulmi n. s., adult female.

Fig. 5. Last segment of same.

*All the drawings for this paper were made, under the author's direction, by Miss Lydia M. Hart, Artist of the Laboratory. 


\section{Plate XXXiII.}

Fig. 1. Chionaspis americana n. s., on elm leaf and twig, showing both male and female scales.

\section{Plate IXITIT.}

Fig. 1. Chionaspis americana n. s.: a, adult male, perfect form ; $b$, antenna; $c$, tarsus.

Fig. 2. Adult male of same, stub-winged form.

Fig. 3. Young larva of same species.

Fig. 4. Adult female of same species.

Fig. 5. Last segment of same. 